\title{
Natural parasitism of Diaphorina citri Kuwayama (Hemiptera, Psyllidae) nymphs by Tamarixia radiata Waterston (Hymenoptera, Eulophidae) in São Paulo orange groves
}

\author{
Paulo Eduardo Branco Paiva ${ }^{1,2} \&$ José Roberto Postali Parra ${ }^{1}$
}

\begin{abstract}
${ }^{1}$ Departamento de Entomologia e Acarologia, Universidade de São Paulo, Escola Superior de Agricultura Luiz de Queiroz,, Avenida Pádua Dias, 11, 13418-900 Piracicaba-SP, Brazil.paulopaiva@usp.br; jrpparra@esalq.usp.br ${ }^{2}$ Corresponding author.
\end{abstract}

\begin{abstract}
Natural parasitism of Diaphorina citri Kuwayama (Hemiptera, Psyllidae) nymphs by Tamarixia radiata Waterston (Hymenoptera, Eulophidae) in São Paulo orange groves. The psyllid Diaphorina citri Kuwayama 1908 has become the main citrus pest species in the state of São Paulo, Brazil, after the introduction of the huanglongbing or citrus greening. This study evaluated the parasitism of $3^{\text {rd }}, 4^{\text {th }}$ and $5^{\text {th }}$ instar D. citri nymphs by Tamarixia radiata (Waterston, 1922) in citrus groves under a regimen of regular insecticide applications in ten producing regions: Araraquara, Barretos, Bauru, Botucatu, Franca, Itapetininga, Jaú, Limeira, Lins and São João da Boa Vista. Sixty-nine samples of new branches infested with nymphs of D. citri were collected from 2005 to 2008 in orange groves ranging from 1 to 20 years old, of the varieties Hamlin, Pera, Valencia and Natal. The parasitoid T. radiata is widely distributed in São Paulo orange groves, and was identified in $50(72 \%)$ of the samples, showing a mean parasitism rate of $12.4 \%$. The highest parasitism rate was observed in the "summer" (from January through March), with a mean of $25.7 \%$. Nymphal parasitism was above $90 \%$ in two samples. The probable causes of the variations in parasitism of $D$. citri by $T$. radiata are discussed.

KEYWORDS. Biological control; psyllid; Citrus, ectoparasitoid.

RESUMO. Parasitismo natural de ninfas de Diaphorina citri Kuwayama (Hemiptera, Psyllidae) por Tamarixia radiata Waterston (Hymenoptera, Eulophidae) em pomares de laranja em São Paulo. O psilídeo Diaphorina citri Kuwayama 1908 tornou-se a principal praga dos citros no estado de São Paulo após a introdução do huanglongbing ou grenning dos citros. Este estudo avaliou as proporções de ninfas de terceiro a quinto ínstares de D. citri parasitadas por Tamarixia radiata (Waterston, 1922) em pomares de laranja submetidos a pulverizações constantes de inseticidas em dez regiões produtoras, Araraquara, Barretos, Bauru, Botucatu, Franca, Itapetininga, Jaú, Limeira, Lins e São João da Boa Vista. Foram coletadas 69 amostras de ramos jovens infestados com ninfas de $D$. citri obtidas entre 2005 e 2008 em pomares de 1 a 20 anos de idade, das cultivares Hamilin, Pera, Valencia e Natal. O parasitóide T. radiata encontra-se amplamente distribuído em pomares de São Paulo, tendo sido observado em 50 amostras (72\%), com taxa média de parasitismo de $12.4 \%$. O maior parasitismo foi verificado no "verão" (janeiro a março) com média de $25.7 \%$. O parasitismo de ninfas superou $90 \%$ em duas amostras. São discutidas as causas próváveis das variações entre o parasitismo de D. citri por T. radiata.
\end{abstract}

PALAVRAS CHAVE. Controle biológico; psilídeo; Citrus, ectoparasitóide.

The citrus psyllid, Diaphorina citri Kuwayama 1908 (Hemiptera, Psyllidae), has become the main citrus pest in the state of São Paulo in the past few years, after the introduction of the bacteria associated with huanglongbing (HLB, citrus greening), Candidatus Liberibacter asiaticus and Candidatus Liberibacter americanus (Coletta-Filho et al. 2004; Teixeira et al. 2005), both transmitted by this insect (Aubert 1987b; Bové 2006). Aggressive chemical control of the vector with the aim of excluding it from citrus groves has been recommended as part of programs to reduce HLB damage. However, frequent and intensive use of insecticides has already resulted in a lower population susceptibility to the main insecticides (Tiwari et al. 2011), as well as an increase in non-target pests, especially scales, and also a significant increase in citrus production costs (Fukuda et al. 2010).

Although D. citri has been recorded in Brazil for more than 70 years (Costa Lima 1942), it was considered a minor pest because of the direct damage that it caused, and has been relatively little studied. Until 2004, there were no records of the occurrence of parasitoids or predators of this species (Aubert 1987a; Paiva 1996), until nymphs parasitized by the eulophid Tamarixia radiata (Waterston, 1922) (Hymenoptera, Eulophidae) were found in several regions of São Paulo state (Gómez Torres et al. 2006). Biological control of D. citri has been considered insufficient for disease control (Halbert \& Manjunath 2004), although there are cases of successful classical biological control (Aubert 1987b; Etienne et al. 2001). The parasitoid $T$. radiata was recently introduced into the Americas, where its efficiency on D. citri has varied considerably, with high parasitism rates in Puerto Rico, with a mean of $70 \%$, reaching $100 \%$ in some locations (Pluke et al. 2008), and very low rates in the U.S.A. (Florida), between 1 and 3\% (Michaud 2004; Qureshi \& Stansly 2009). In São Paulo, early estimates of parasitism rates varied from 27.5 to $80 \%$ (Gómez Torres et al. 2006; Parra et al. 2010).

The idiobiont ectoparasitoid T. radiata is native to northern India, where it develops on $D$. citri nymphs, preferentially those in the $3^{\text {rd }}$ to $5^{\text {th }}$ instars (Etienne et al. 2001), and is con- 
sidered a specialist parasitoid (Zuparko et al. 2011). The female $T$. radiata also kills its host by feeding, and one female can cause the death of up to 500 nymphs from feeding and parasitism (Hoy \& Nguyen 2001). The life cycle of $T$. radiata in $D$. citri is slightly more than 10 days at $25^{\circ} \mathrm{C}$, a temperature which results in the highest reported parasitism rate, a mean of 167 psyllid nymphs per female (Parra et al. 2010).

Since $T$. radiata was first recorded in Brazil, samples of citrus psyllid nymphs have been collected from various areas to estimate its abundance and efficiency. The objective of this study was to estimate the parasitism rates of large nymphs of $D$. citri by $T$. radiata in orange groves under a regime of frequent insecticide applications, mainly to control D. citri, in the main producing regions of São Paulo, during a four- year period.

\section{MATERIAL AND METHODS}

Groves of the four main varieties of sweet oranges Citrus sinensis Osbeck grown in São Paulo: Hamlin, Pera, Valencia and Natal, were sampled from the beginning of 2005 until mid-2008 to obtain estimates of nymphal parasitism in the citrus psyllid $D$. citri by the eulophid $T$. radiata. Nineteen groves, managed according to current horticultural practices, were chosen, distributed in ten regions: Araraquara, Barretos, Bauru, Botucatu, Franca, Itapetininga, Jaú, Limeira, Lins and São João da Boa Vista.

The samples consisted of new orange-tree branches with large nymphs of $D$. citri, preferably $4^{\text {th }}$ and $5^{\text {th }}$ instars, which were removed and placed in paper bags. Sampling was carried out randomly in the plot where the psyllid occurred, for about one hour. Samples with more insects were collected from those plots with the highest nymphal infestations; and where infestations were low, the samples contained fewer insects. Sixty-nine samples were collected, with a mean sample size of 195 nymphs, ranging from 19 to 972 insects.

The groves were between 1 and 20 years old, with the age being the difference between the planting year and the year when the trees were sampled. To study the effect of the time of year on parasitism, the January-March period was adopted as austral "summer", with 22 samples; from April through June as "autumn", with 21 samples; July through September as "winter", with 8 samples; and October through December as "spring", with 18 samples. The municipalities where the samples were taken were grouped according to the classification of agricultural regions by the state Department of Agriculture.

Parasitism was evaluated the same day as the samples were taken, using a stereoscopic microscope. The parasitized nymphs contained eggs or young larvae of the parasitoid on their bodies, or they were mummified. The percentage parasitism rates were calculated from the ratio between the number of parasitized nymphs and the total number of parasitized and non-parasitized nymphs.

In some areas, in addition to collecting samples to quantify parasitism, psyllid infestation was estimated by sampling
60 new branches and calculating the ratio of new branches with nymphs to all instars and adult psyllids, with the aim of relating parasitism to host infestation.

The decimal data for the number of parasitized nymphs and the total number of nymphs were transformed, $\mathrm{y}=$ arc sine $\mathrm{x}^{1 / 2}$, and submitted to analyses of variance with the $\mathrm{F}$ test, comparing the effect of the year, the time of year (season), the region, the grove age and the orange variety, as well as the dependence of parasitism on estimated host density. The software SAS (2000) was used. The seven samples collected from groves with more than one orange variety were excluded from the analysis of the effect of this variable.

\section{RESULTS}

Sixty-nine samples were collected from 2005 to 2008. A total of $13,474 D$. citri nymphs of the $3^{\text {rd }}$ to the $5^{\text {th }}$ instars were observed during the study, of which 1,672 nymphs (12.4\%) were parasitized by $T$. radiata. The distribution of samples in the regions and between years is given in Table I. Of the 69 samples, 19 had no parasitized $D$. citri that is slightly more than one-quarter of the samples. A larger group of samples, $36.2 \%$, showed parasitism rates varying between 1 and $10 \%$, and $10.1 \%$ of the samples showed parasitism percentages between 11 and $20 \%$. Thus, almost $75 \%$ of the samples had no $T$. radiata or had a parasitism rate below $20 \%$.

Table I. Number of samples of new branches of orange trees with Diaphorina citri nymphs, in orange groves in 10 regions of the state of São Paulo, taken during each year of the study.

\begin{tabular}{clcccc}
\hline \multirow{3}{*}{ North } & \multicolumn{1}{c}{ Region } & 2005 & 2006 & 2007 & 2008 \\
& Barretos & 5 & 1 & & 1 \\
& Franca & & 1 & 4 & 2 \\
South & Araraquara & 6 & 2 & 3 & \\
& Bauru & 3 & & 4 & 1 \\
& Jaú & 1 & & & 1 \\
& Botucatu & 1 & 1 & 3 & \\
& Itapetininga & & & 1 & 1 \\
& Limeira & 5 & 3 & 2 & \\
& S J Boa Vista & 2 & & & \\
\hline \multirow{7}{*}{ West } & Lins & 11 & & 4 &
\end{tabular}

On the other hand, parasitism rates between 31 and 50\% were observed in nine samples, (13\% of the total), and seven $(10 \%)$ of the samples had more than $50 \%$ parasitism. In two samples, more than $90 \%$ of the nymphs were parasitized.

There was a negative relationship between the parasitism rate ( $\%$ between parasitized and total nymphs) and the percentage of branches with $D$. citri nymphs $(\mathrm{F}=4.7024, \mathrm{df}=$ $1,27, \mathrm{p}=0.0390)$, but there was no relationship between the nymphal parasitism rate and the percentage of branches infested with adult $D$. citri $(\mathrm{F}=0.1223$, $\mathrm{df}=1,25, \mathrm{p}=$ 0.7295). Therefore, for lower nymph infestations, parasitism rates were the highest for this stage, suggesting that even in 
low $D$. citri infestations there may be $T$. radiata parasitism under field conditions.

The highest parasitism rate during the four-year study period was in 2008 , with a mean of $35.5 \%$ of nymphs parasitized; and the lowest rate was in 2007, with $5.4 \%$ (Table II). In 2008, one of the samples collected in the Jaú region, municipality of Itajú, in February, had $91.7 \%$ parasitism. On the other hand, in 2007, the highest percentage, $32.4 \%$, was observed in the Limeira region, municipality of Analândia, in September. In 2005 and 2006, intermediate parasitism rates were recorded.

The season with the highest parasitism rate of $D$. citri nymphs was the summer (January through March), when temperatures are high and rainfall is abundant in São Paulo, resulting in many new branches being available for citrus psyllid feeding and oviposition. The mean rate observed during this period was $25.7 \%$, followed by autumn (April through June) with $14.6 \%$ of nymphs with $T$. radiata, although one sample in each season showed more than $90 \%$ parasitism.

There was no statistical difference in the parasitism rates between regions, suggesting that $T$. radiata is well adapted to the climatic conditions where oranges are grown in São Paulo (Table II). The two samples with more than $90 \%$ parasitism were found in the central region, one in Itajú and the other in Pederneiras municipality.

Two characteristics of the orange groves where samples were taken were compared: grove age and the orange variety. There were no statistically significant differences in the observed parasitism rate between the grove age ranges compared, even though the mean rate observed in 4 to 6 -year-old groves was $24.6 \%$, almost four times higher than the estimated $6.6 \%$ rate in the younger 1 to 3 -year-old groves. However, the orange variety significantly affected parasitism, with high parasitism levels observed in nymphs on the early-maturing Hamlin variety compared to the later-maturing Valencia and Natal varieties.

\section{DISCUSSION}

The ectoparasitoid Tamarixia radiata is the best studied natural enemy of Diaphorina citri in the world, and has been introduced into several countries for classical biological control, including Réunion, China, Indonesia, Malaysia and, more recently, the U.S.A., in 1998, and into Guadeloupe in 1999 (Chien et al. 1989; Etienne et al. 2001; Hoy \& Nguyen 2001). In other countries of the Americas (Puerto Rico, Mexico, Brazil and Argentina), T. radiata was only recorded after its introduction into the U.S.A. and Guadeloupe.

In the 1980s, Aubert (1987a) found no parasitoids in the D. citri populations of three Brazilian states, Bahia, São Paulo and Sergipe. The same author found that these populations were highly parasitized by $T$. radiata in the laboratory, and recommended its introduction into Brazil.

The most successful case of biological control of $D$. citri by $T$. radiata has been described in Reunion Island, and attributed to the local absence of hyperparasitoids (Aubert 1987b; Etienne et al. 2001). In the U.S.A., low levels of parasitism of $D$. citri were attributed to the high predation of parasitized nymphs (Michaud 2004; Qureshi \& Stansly 2009). Since no hyperparasitoids or even predators of $D$. citri nymphs have

Table II. Percentage of parasitism of $4^{\text {th }}$ and $5^{\text {th }}$ instar nymphs of Diaphorina citri by Tamarixia radiata, between 2005 and 2008 , in orange groves of different ages and varieties in São Paulo.

\begin{tabular}{|c|c|c|c|c|c|c|c|c|}
\hline & & $\mathrm{n}$ & mean & $\min$ & $\max$ & value $\mathrm{F}^{1}$ & df (treat,res) & $\mathrm{p}$ \\
\hline \multirow[t]{4}{*}{ Year } & 2005 & 34 & 20.0 & 0.0 & 91.6 & 3.5445 & 3,65 & 0.0192 \\
\hline & 2006 & 8 & 12.8 & 0.0 & 67.7 & & & \\
\hline & 2007 & 21 & 5.4 & 0.0 & 32.4 & & & \\
\hline & 2008 & 6 & 35.5 & 0.0 & 91.7 & & & \\
\hline \multirow[t]{4}{*}{ "Season" } & “spring" (Oct-Dec) & 18 & 10.7 & 0.0 & 67.7 & 3.0722 & 3,65 & 0.0338 \\
\hline & “summer” (Jan-Mar) & 22 & 25.7 & 0.0 & 91.7 & & & \\
\hline & “autumn” (Apr-Jun) & 21 & 14.6 & 0.0 & 91.6 & & & \\
\hline & “winter” (Jul-Sep) & 8 & 5.6 & 0.0 & 32.7 & & & \\
\hline \multirow[t]{4}{*}{ Region } & North & 14 & 13.3 & 0.0 & 66.7 & 0.4388 & 3,65 & 0.7259 \\
\hline & Center & 20 & 20.9 & 0.0 & 91.7 & & & \\
\hline & West & 16 & 11.4 & 0.0 & 43.7 & & & \\
\hline & South & 19 & 16.9 & 0.0 & 67.7 & & & \\
\hline \multirow[t]{4}{*}{ Grove age (yr) } & $1-3$ & 15 & 6.6 & 0.0 & 67.7 & 2.3331 & 3,65 & 0.0821 \\
\hline & $4-6$ & 20 & 24.6 & 0.0 & 91.6 & & & \\
\hline & $7-9$ & 17 & 12.6 & 0.0 & 66.7 & & & \\
\hline & $10+$ & 13 & 18.6 & 0.0 & 91.7 & & & \\
\hline \multirow[t]{4}{*}{ Orange variety } & Hamlin & 11 & 35.6 & 1.0 & 91.7 & 4.3048 & 3,58 & 0.0082 \\
\hline & Pera & 15 & 20.1 & 0.0 & 67.7 & & & \\
\hline & Valencia & 31 & 9.1 & 0.0 & 43.7 & & & \\
\hline & Natal & 5 & 7.3 & 0.0 & 30.4 & & & \\
\hline
\end{tabular}

${ }^{1}$ Analyses of variance, by the $\mathrm{F}$ test, with the ratios of the number of parasitized nymphs/total nymphs transformed to arc sine $\mathrm{x}{ }^{1 / 2}$. 
been observed in Brazil, the low parasitism rates observed in this study could be due to the absence of nymphs for feeding and parasitism by T. radiata. Intensive insecticide use for psyllid control, including aerial applications, may kill the parasitoids (Hall \& Nguyen 2010) and limit parasitoid action. Genetic differences between the T. radiata populations in Central and North America have recently been found (Barr et al. 2009), which may be another cause for the differences in efficiency.

Estimates of parasitism rates based on the ratio of parasitized and total nymphs or on the ratio of emerged $T$. radiata adults to $D$. citri represent an attempt to quantify the efficiency of the natural enemy in field conditions. However, these rates may not represent the true importance of the natural enemy as a mortality factor and regulator of the insectpest population. In the case of $T$. radiata, the nymphal mortality caused by female feeding is greater than the parasitism itself (Skelley \& Hoy 2004), and this factor was not evaluated in the present study.

However, parasitism rates in the field are easily obtained and, as in the present study, can be estimated in different locations over time. Although samples with no parasitism or with rates of less than $20 \%$ predominated, $T$. radiata is widely distributed throughout the orange-producing regions of São Paulo, and should be protected in integrated pest and disease management programs in citrus.

The highest percentages of parasitism were observed in São Paulo in the summer and autumn, and the lowest percentage in the winter. However, in Florida, U.S.A., parasitism rates were lower than $20 \%$ in spring-summer and increased to 39 to $56 \%$ in the autumn (Qureshi et al. 2009). In China, a $36 \%$ parasitism rate was observed on new branches in the summer, and $46 \%$ on branches in the autumn (Yang et al. 2006). The results of the present study also showed that there were no differences in parasitism between the northern, central, western and southern regions of São Paulo, confirming the wide distribution of $T$. radiata. Considering that this insect was probably introduced by the end of the 1990s, there has already been wide natural dispersal.

In younger groves (1-3 years old), parasitism rates were one-fourth of the rates found in mature groves (4-6 years old), although the differences were not statistically significant. Young trees may be less suitable for T. radiata parasitism, or these groves may have been under more aggressive psyllid control regimens, since the damage caused by HLB is more severe in young plants.

The psyllid $D$. citri develops differently on different species of Citrus and other genera of Rutaceae, such as Murraya (Nava et al. 2007). However, there was no difference in $D$. citri development between the Pera and Natal varieties of $C$. sinensis (Nava et al. 2010). The parasitoid can use the host plant of its prey to locate it, and therefore, the Hamlin variety may be more attractive than the Valencia and Natal varieties, although this hypothesis must be validated by further research.

The occurrence of T. radiata in São Paulo orange groves depends on the presence of host nymphs, preferably those in the $4^{\text {th }}$ and $5^{\text {th }}$ instars. However, the persistence of the parasi- toid in the environment appears to be incompatible with the current situation of HLB in São Paulo, where some growers have not eliminated diseased trees, thus increasing the disease reservoir and requiring those growers who have eliminated the inoculum to use insecticides even more aggressively to control the vector.

\section{REFERENCES}

Aubert, B. 1987a. Le psylle asiatique des agrumes (Diaphorina citri Kuwayama) au Brésil. Situation actuelle et perspectives de lutte. Fruits 42: 225-229.

Aubert, B. 1987b. Trioza erytreae (Del-Guercio) and Diaphorina citri Kuwayama (Homoptera, Psylloidea), the two vectors of citrus greening disease: biological aspects and possible control strategies. Fruits 42: 149-162.

Barr, N. B.; D. G. Hall; A. A. Weathersbee III; R. Nguyen; P. Stansly; J. A. Qureshi \& D. Flores. 2009. Comparison of laboratory colonies and field populations of Tamarixia radiata, an ectoparasitoid of the Asian citrus psyllid, using internal transcribed spacer and cytochrome oxidase subunit I DNA sequences. Journal of Economic Entomology 102: 2325-2332.

Bové, J. M. 2006. Huanglongbing: a destructive, newly-emerging, centuryold disease of citrus. Journal of Plant Pathology 88: 7-37.

Chien, C. C.; S. C. Chiu \& S. C. Ku. 1989. Biological control of Diaphorina citri in Taiwan. Fruits 44: 401-407.

Coletta-Filho, H. D.; M. L. P. N. Targon; M. A. Takita; J. D. De Negri; J. Pompeu Jr; M. A. Machado; A. M. do Amaral \& G. W. Muller. 2004. First report of the causal agent of huanglongbing ("Candidatus Liberibacter asiaticus") in Brazil. Plant Disease 88: 1382.

Costa Lima, A. M. 1942. Insetos do Brasil: Homoptera. Escola Nacional de Agronomia, Rio de Janeiro, 3: 141p.

Étienne, J.; S. Quilici; D. Marival \& A. Franck. 2001. Biological control of Diaphorina citri (Hemiptera: Psyllidae) in Guadeloupe by imported Tamarixia radiata (Hymenoptera: Eulophidae). Fruits 56: 307-315.

Fukuda, L.A.; D. Franco; S. L. Facio \& R. de S. Lima Neto. 2010. Sustentabilidade econômica da citricultura perante o huanglongbing. Citrus Research \& Technology 31: 107-114.

Halbert, S. E. \& K. L. Manjunath. 2004. Asian citrus psyllids (Sternorrhyncha: Psyllidae) and greening disease of citrus: A literature review and assessment of risk in Florida. Florida Entomologist 87: 330-353.

Hall, D. G. \& R. Nguyen. 2010. Toxicity of pesticides to Tamarixia radiata, a parasitoid of the Asian citrus psyllid. BioControl 55: 601-611.

Hoy, M. A. \& R. Nguyen. 2001. Classical biological control of Asian citrus psylla. Citrus Industry 81: 48-50.

Michaud, J. P. 2004. Natural mortality of Asian citrus psyllid (Homoptera: Psyllidae) in central Florida. Biological Control 29: 260-269.

Nava, D. E.; M. L. Gomez-Torres; M. D. Rodrigues; J. M. S. Bento; M. L. Haddad \& J. R. P. Parra. 2010. The effects of host, geographic origin, and gender on the thermal requirements of Diaphorina citri (Hemiptera: Psyllidae). Environmental Entomology 39: 678-684.

Nava, D. E.; M. L. G. Torres; M. D. L. Rodrigues; J. M. S. Bento \& J. R. P. Parra. 2007. Biology of Diaphorina citri (Hem., Psyllidae) on different hosts and at different temperatures. Journal of Applied Entomology 131: 709-715.

Paiva, P. E. B. 1996. Flutuação populacional da Diaphorina citri (Hemiptera, Psyllidae) em citros no estado de São Paulo. Laranja 17: 254-255.

Parra, J. R. P.; J. R. S. Lopes; M. L. G. Torres; D. E. Nava \& P. E. B. Paiva 2010. Bioecologia do vetor Diaphorina citri e transmissão de bactérias associadas ao huanglongbing. Citrus Research \& Technology 31: 37-51

Pluke, R. W. H.; J. A. Qureshi \& P. A. Stansly. 2008. Citrus flushing patterns, Diaphorina citri (Hemiptera: Psyllidae) populations and parasitism by Tamarixia radiata (Hymenoptera: Eulophidae) in Puerto Rico. The Florida Entomologist 91: 36-42. 
Qureshi, J. A.; M. E. Rogers; D. G. Hall \& P. A. Stansly. 2009. Incidence of invasive Diaphorina citri (Hemiptera: Psyllidae) and its introduced parasitoid Tamarixia radiata (Hymenoptera: Eulophidae) in Florida citrus. Journal of Economic Entomology 102: 247-256.

Qureshi, J. A. \& P. A. Stansly. 2009. Exclusion techniques reveal significant biotic mortality suffered by Asian citrus psyllid Diaphorina citri (Hemiptera: Psyllidae) populations in Florida citrus. Biological Control 50: $129-136$.

SAS Institute. 2000. SAS Users Guide: Statistics version 8.02 for Windows. SAS Institute, Inc., Cary.

Skelley, L. H. \& M. A. Hoy. 2004. A synchronous rearing method for the Asian citrus psyllid and its parasitoids in quarantine. Biological Control 29: 14-23.

Teixeira, D. C.; C. Saillard; S. Eveillard; J. L. Danet; P. I. Costa; A. J. Ayres \& J. Bové. 2005. 'Candidatus Liberibacter americanus', associated with citrus huanglongbing (greening disease) in São Paulo State, Brazil. International Journal of Systematic and Evolutionary Microbiology
55: $1857-1862$.

Tiwari, S.; R. S. Mann; M. E. Rogers \& L. L. Stelinski. 2011. Insecticide resistance in field populations of Asian citrus psyllid in Florida. Pest Management Science 67: 1258-1268.

Torres, M. L.G.; D. E. Nava; S. Gravena; V. A. Costa \& J. R. P. Parra. 2006. Registro de Tamarixia radiata (Waterston) (Hymenoptera: Eulophidae) em Diaphorina citri Kuwayama (Hemiptera: Psyllidae) em São Paulo, Brasil. Revista de Agricultura 81: 112-117.

Yang, Y.; M. Huang; G. Andrew; C. Beattie; Y. Xia; G. Ouyang \& J. Xiong. 2006. Distribution, biology, ecology and control of the psyllid Diaphorina citri Kuwayama, a major pest of citrus: a status report for China. International Journal of Pest Management 52: 343-352.

Zuparko, R. L.; D. L. de Queiroz \& J. La Salle. 2011. Two new species of Tamarixia (Hymenoptera: Eulophidae) from Chile and Australia, established as biological control agents of invasive psyllids (Hemiptera: Calophyidae, Triozidae) in California. Zootaxa 2921: 13-27. 